\title{
The process of designing interior textile products $\&$ the influence of Design for the Environment (DfE)
}

Sage Calamari ${ }^{*}$ and Karen H Hyllegard

\author{
* Correspondence: \\ sagecalamari@gmail.com \\ Department of Design and \\ Merchandising, Colorado State \\ University, 150 Aylesworth SE, Fort \\ Collins, CO 80523-1574, USA
}

\begin{abstract}
This study examined the processes involved in the design of interior textile products, with emphasis upon processes undertaken by designers' who are committed to a Design for the Environment (DfE) orientation. Handfield et al. (IEEE TEM 48:189-208, 2001) model of product design and development provided a context by which to explore inclusion of environmental performance criteria within the design process. Data were collected through interviews with twelve professional designers of interior textile products. Analyses revealed six themes or stages in the design process for interior textile products: resources and research, consumer need and trend identification, inspiration, creative exploration, product samples, and design completion. DfE-oriented designers and conventional designers did not differ in their narratives regarding design process however, the focus and scope of decision-making within each theme or stage allowed for an additional component to the DfE-oriented design and development process of interior textile products.
\end{abstract}

Keywords: Interior textiles; Design process; Design for the Environment (DfE)

\section{Springer}

\section{Introduction}

Since the 1960s, researchers have attempted to understand the step-by-step processes that designers use to create a variety of products, including textiles (Watkins, 1988). More recently, researchers have linked decisions made during the design process to the financial and environmental impacts of products (Ramani et al., 2010), and have begun to examine the relationship between design, production, and sustainability (McDonough and Braungart, 2002). This includes the role that designers play in the development of textile and apparel products and the possibility that design processes may enhance the environmental sustainability of such products (Kim, 2010; Fuad-Luke, 2009; Margolin, 2007; Ramani et al., 2010; Stegall, 2006). To date, however, researchers have not fully explored the role that designers play in the development of interior textiles, which includes decorative items in the home such as, bedding, pillows, upholstery and rugs, or how the development of these textiles may be influenced by designers' concerns for human health and the environment.

Design for the Environment (DfE), a term introduced in the 1990s, refers to a shift in product development and planning methods/processes wherein both environmental and economic factors guide the direction of design decisions (Kim, 2010; Ramani et al., 
2010; Yang et al. 2011). DfE reflects an emerging perspective that designers can act as instruments of social change by reducing the negative impact that products have on human health and the environment through decisions related to raw material selection, manufacturing methods, and product use, care, and disposal (Kim, 2010; Fuad-Luke, 2009; Ramani et al., 2010; Stegall, 2006). Despite the negative impacts that interior textiles often have on human health and the environment, as well as how decisions made during the design process may lessen these impacts, to date there are few published studies on the processes of professional designers engaged in creating textile products, including interior textiles, or whether such processes involve the integration of DfE-oriented approaches to design.

Thus, the purpose of this research was to gain understanding of the processes that guide the design of interior textile products. Of particular interest was how commitment to a Design for the Environment (DfE) orientation influenced the processes undertaken by professionals engaged in the design of interior textile products. Examinations of design processes, including evolving social and technological impacts on these processes, are important because a designer's reflection upon his/her process can contribute to theory building and add to the body of knowledge in the discipline (Bye, 2010).

\section{Literature review}

Design process

The design process, involves "a sophisticated mental process capable of manipulating many kinds of information, blending them all into a coherent set of ideas and, finally, generating some realization of those ideas" (Lawson, 1997, p. 10). A critical component of this definition is the word 'information' as it is through the processing of information that designers create a foundation for generating design solutions (Watkins, 1988). Designers gather information to achieve a desired outcome or solve a particular problem, such as an approach to developing more environmentally sustainable products. Theorist Margolin (2007) described designers as "creators of models, prototypes and propositions, [who] occupy a dialectical space between the world that is and the world that could be" (p. 4). Margolin's definition implies that the role of designers is to engage in imaginative exploration that fosters solutions to present and future societal needs. As such, designers have the opportunity to envision and enact solutions to diverse issues surrounding human health and environmental sustainability (Fuad-Luke, 2009).

It has been argued that designers often jump between "rational periods of thought and the imaginative periods they might identify as creative thinking" (Watkins, 1988, p. 336). Thus, suggesting that there is no singular way to approach design. Commonalities have been identified across fields (Gagnon et al. 2012; LaBat and Sokolowski, 1999), however, and varied approaches have been adopted and modified for application in diverse fields, and especially for the advancement of education in those fields (LaBat and Sokolowski, 1999; Laamanen and Seitamaa-Hakkarainen, 2008). For example, Lamb and Kallal (1992) explored the importance of the design process in the development of apparel for disabled consumers. The researchers introduced a six-step design process framework - problem identification, preliminary ideas, design refinement, prototype development, evaluation, and implementation-that addressed consumers' functional, expressive, and aesthetic needs (Lamb and Kallal, 1992). 
LaBat and Sokolowski (1999) examined the role of the design process across multiple fields in order to bridge the gap between academia and industry. The researchers identified three stages common to the design process across fields: problem definition and research, creative exploration, and implementation (LaBat and Sokolowski 1999). The researchers subsequently defined and expanded upon each stage of the process to more adequately explain the apparel design process. Specifically, the researchers expanded the conceptualization of the creative exploration stage to include ideation, design refinement, prototyping, and evaluation of the prototype (LaBat and Sokolowski, 1999). The researchers concluded that a systematic approach to design was beneficial in fostering communication between the design team and industry professionals and in contributing to an adequate design solution, and, in turn, further demonstrated the value of the design process (LaBat and Sokolowski, 1999).

\section{Design for the Environment (DfE)}

Design for the Environment (DfE) involves giving consideration to both economic and environmental influences during the design process (Kim, 2010; Ramani et al., 2010; Yang et al., 2011). More specifically, a DfE orientation involves meeting five criteria or goals: choosing ecological materials, extending the life cycle of the product within the design, increasing recyclability, minimizing environmental damage in disposal, and calculating energy waste in production and distribution, which are considered during both product design and product evaluation (Kim, 2010).

DfE approaches to textile and apparel design include: cradle to cradle (Gam et al. 2009), design for disassembly (Gam et al. 2011), slow design (Clark, 2008), and green fashion design (Kim, 2010). Much of the prior research examining DfE approaches to textile and apparel design has involved model building and prototyping. For example, in one study integrating cradle to cradle principles into apparel design, a sustainable product design process model was developed and tested through the creation of children's knitwear (Gam et al., 2009). The prototype garments were analyzed for performance, cost, and the triple bottom line of sustainability (i.e., economic, social, and environmental criteria) and were determined to be an improvement upon current textile and apparel design and production with respect to mitigating negative human health and environmental impacts (Gam et al., 2009).

\section{Conceptual framework}

This examination of the processes that guide of the design of interior textiles products, with emphasis upon DfE-oriented approaches to design, was informed by prior examinations of the textile and apparel design process (Lamb and Kallal 1992; LaBat and Sokolowski, 1999; Studd, 2002) as well as Handfield et al.'s (2001) model of product design and development. Specifically, this model provided a context by which to explore the inclusion of environmental performance criteria within the interior textile design process.

Drawing from their examination of the integration of environmental issues into the product design process, Handfield et al. (2001) developed a conceptual model to assist businesses in making environmentally responsible decisions with respect to product design and development. The model is based upon three propositions about ecologically 
sustainable organizations. First, designers in these organizations give explicit consideration to environmental issues to meet corporate and product design goals. Second, such organizations explicitly measure environmental objectives or criteria at major points throughout the product design process, and that these environmental criteria carry equal weight to other performance criteria. Third, such organizations integrate environmental issues into the design process by measuring environmental outcomes and incorporating outcomes into strategic planning (Handfield et al., 2001).

The second proposition was of greatest interest for the present study because it focuses directly upon the product design/development process, which is conceptualized as a five step process that includes: concept, product design, process design, package design, and product launch, as well as the systems that may be utilized to support the design process (Handfield et al., 2001). At the center of this proposition is the idea that environmental objectives or criteria can be encouraged and evaluated during each stage of the design process. During the concept stage designers are engaged in creative exploration to identify potential environmental problems and develop DfE-oriented solutions, which may include identifying environmentally sustainable material options and ideas for use and disposal planning. Once the concept is developed the designer focuses upon the "three P's", product, process and packaging, to positively influence environmental outcomes. Within the "three P's" the designer makes decisions related to product specifications (i.e., raw material), the manufacturing and assembly plan, and decisions regarding how finished product will be packed for shipping. The final step, product launch, provides an opportunity for the designers to assess the environmental impacts of the product using existing DfE assessment tools with the help of sustainability experts.

The present study contributes to our understanding of the processes that guide the design and development of interior textile products, including designers' commitment to a Design for the Environment (DfE) perspective, by addressing two research questions:

RQ1: How do designers of interior textile products delineate the product design process?

RQ2: What similarities or differences exist with respect to how conventional designers and designers with a DfE orientation delineate the design process for interior textiles products?

\section{Method}

A qualitative research approach was employed for this study to examine the processes that guide the design of interior textile products. Specifically, interviews with design professionals working in the interior textile industry were conducted to gain understanding of the design processes that are employed in a professional business setting.

\section{Participants/companies}

Purposive sampling was employed to identify potential participants who possessed expertise in the design of interior textile products. Potential participants were 
identified through a search of company websites, trade organizations and publications, and textile certification bodies. The participant group included twelve textile designers and design managers who specialize in the development of interior textiles using conventional and/or DfE-oriented approaches to product design. Participants varied with respect to job titles, professional backgrounds, and years of experience in the textile design industry. All of the participants were employed by companies that are headquartered in the United States. The companies at which the participants worked differed by size (number of employees), product offerings, types of business operations, and in their commitment to DfE approaches to design. The companies' product offerings included general use textiles, contract textiles, furniture, and home goods (i.e., bedding, tablecloths, etc.). Although the companies varied in size and orientation, from small firms strictly engaged in the design of textiles to large firms that are actively involved in multiple stages of the supply chain including the manufacturing of textiles, the sample provided situational representativeness with respect to the participants' expertise with the design process for interior textile products. Participant and company profiles are presented in Table 1.

Table 1 Profile of participants and companies

\begin{tabular}{|c|c|c|c|c|c|c|}
\hline $\begin{array}{l}\text { Professional } \\
\text { title }\end{array}$ & $\begin{array}{l}\text { Years in } \\
\text { textile } \\
\text { industry }\end{array}$ & $\begin{array}{l}\text { Company } \\
\text { headquarters } \\
\text { (US Regions) }\end{array}$ & $\begin{array}{l}\text { Company } \\
\text { size (\# of } \\
\text { employees) }\end{array}$ & Business type & $\begin{array}{l}\text { Product } \\
\text { types }\end{array}$ & $\begin{array}{l}\text { DfE } \\
\text { orientation }\end{array}$ \\
\hline $\begin{array}{l}\text { President/ } \\
\text { Designer }\end{array}$ & $1-10$ & Pacific Northwest & $1-10$ & $\begin{array}{l}\text { Wholesale } \\
\text { printed textile }\end{array}$ & $\begin{array}{l}\text { Textile } \\
\text { home } \\
\text { goods }\end{array}$ & Yes \\
\hline Artist & $1-10$ & Rocky Mountain & $1-10$ & $\begin{array}{l}\text { Artisanal woven } \\
\text { textile and } \\
\text { furniture }\end{array}$ & $\begin{array}{l}\text { Artisanal } \\
\text { furniture }\end{array}$ & No \\
\hline Owner/Designer & $10-20$ & $\begin{array}{l}\text { Southern } \\
\text { California }\end{array}$ & $1-10$ & $\begin{array}{l}\text { Wholesale } \\
\text { printed textile }\end{array}$ & $\begin{array}{l}\text { General } \\
\text { textile }\end{array}$ & Yes \\
\hline Creative Director & $20-30$ & $\begin{array}{l}\text { New York } \\
\text { Metropolitan Area }\end{array}$ & Over 1000 & $\begin{array}{l}\text { Wholesale } \\
\text { woven textile }\end{array}$ & $\begin{array}{l}\text { Contract } \\
\text { textile }\end{array}$ & No \\
\hline $\begin{array}{l}\text { Owner/Creative } \\
\text { Director }\end{array}$ & $30-40$ & $\begin{array}{l}\text { Mid Atlantic } \\
\text { States }\end{array}$ & $1-10$ & $\begin{array}{l}\text { Retail printed } \\
\text { textile }\end{array}$ & $\begin{array}{l}\text { General } \\
\text { textile }\end{array}$ & Yes \\
\hline Design Manager & $1-10$ & $\begin{array}{l}\text { New York } \\
\text { Metropolitan Area }\end{array}$ & 50-100 & $\begin{array}{l}\text { Wholesale, } \\
\text { woven textile } \\
\text { manufacturer }\end{array}$ & $\begin{array}{l}\text { Contract } \\
\text { textile }\end{array}$ & Yes \\
\hline Owner/Designer & $10-20$ & New England & $1-10$ & $\begin{array}{l}\text { Wholesale, } \\
\text { textile printer }\end{array}$ & $\begin{array}{l}\text { General } \\
\text { textile }\end{array}$ & No \\
\hline $\begin{array}{l}\text { Product } \\
\text { Development } \\
\text { Assistant }\end{array}$ & $1-10$ & $\begin{array}{l}\text { New York } \\
\text { Metropolitan Area }\end{array}$ & $200-250$ & $\begin{array}{l}\text { Wholesale, } \\
\text { woven textile } \\
\text { manufacturer }\end{array}$ & $\begin{array}{l}\text { Contract } \\
\text { textile and } \\
\text { furniture }\end{array}$ & No \\
\hline $\begin{array}{l}\text { Associate Print } \\
\text { Director }\end{array}$ & $10-20$ & $\begin{array}{l}\text { New York } \\
\text { Metropolitan Area }\end{array}$ & Over 1000 & $\begin{array}{l}\text { Wholesale, } \\
\text { converter }\end{array}$ & $\begin{array}{l}\text { Contract } \\
\text { textile }\end{array}$ & No \\
\hline $\begin{array}{l}\text { Product } \\
\text { Development } \\
\text { Manager }\end{array}$ & $1-10$ & New England & $50-100$ & $\begin{array}{l}\text { Retail print and } \\
\text { woven textile }\end{array}$ & $\begin{array}{l}\text { Textile } \\
\text { home } \\
\text { goods }\end{array}$ & No \\
\hline $\begin{array}{l}\text { Vice President } \\
\text { Research and } \\
\text { Development }\end{array}$ & $20-30$ & $\begin{array}{l}\text { New York } \\
\text { Metropolitan Area }\end{array}$ & $100-150$ & $\begin{array}{l}\text { Wholesale } \\
\text { woven textile }\end{array}$ & $\begin{array}{l}\text { Contract } \\
\text { textile }\end{array}$ & Yes \\
\hline $\begin{array}{l}\text { Senior Textile } \\
\text { Designer }\end{array}$ & $1-10$ & $\begin{array}{l}\text { New York } \\
\text { Metropolitan Area }\end{array}$ & $100-150$ & $\begin{array}{l}\text { Wholesale } \\
\text { woven textile }\end{array}$ & $\begin{array}{l}\text { Contract } \\
\text { textile }\end{array}$ & Yes \\
\hline
\end{tabular}




\section{Data collection}

Potential participants were contacted through email and invited to partake in the study. Upon receipt of a participant's consent to take part in the study, each participant was asked to provide written responses (via email) to questions pertaining to the participant's educational background, years of experience in textile design, and current employment position. Next, telephone interviews were conducted with each participant to obtain information about the processes undertaken to design and develop interior textile products. An in-depth, semi-structured interview approach was employed to help guide responses and ensure that the research questions were addressed as well as to allow for follow-up questions when new ideas or topics were introduced. Interview questions were developed based on the review of literature (e.g. Handfield et al., 2001; Mace, 1997) and were designed to address the stated research questions. Open-ended questions were used to gather data because this approach can better "capture the nature and meaning of creative experience from the perspective of the research participants themselves" (Mace, 1997, p. 226). Example interview questions included, "What tools/aids did you use in designing the [identified] product?" and "What sustainable practices are incorporated at your company related to product design and development?" The interviews ranged from 30 to 80 minutes in duration. The interviews were audio-recorded and upon completion of the data collection were transcribed verbatim. Written transcriptions of the interviews were sent to each participant to verify individual responses to the interview questions. Data collection was concluded when saturation in the participants' responses was realized (Glaser and Strauss, 1967).

\section{Data analysis}

The data collected for this study consisted of written responses to questionnaire items, written transcriptions of audio taped interviews, and hand written notes. Upon completion of the interviews, the transcriptions and notes taken by the primary researcher were read and organized through thematic analysis (Shank, 2002). Open inductive coding was employed to isolate relevant themes in the data (Strauss and Corbin, 1998). Due to the relatively unexplored nature of the research topic, grounded theory and constant comparison approaches were used to systematically code, categorize, and compare the data throughout the data analysis process (Glaser and Strauss, 1967; Glesne, 2011; Strauss and Corbin, 1998). To categorize the data, notes were taken during the initial reading of each transcribed interview in order to isolate important fragments of text (Guetzkow, 1950), which were then used to develop key concepts or meanings in the data as well as to make comparisons across the transcripts. As data analysis continued, concepts and categories were developed into a coding guide that was applied to all twelve interviews. Throughout this process of rereading and analyzing the interview data based upon the established coding guide, themes were identified and compared across the transcripts.

To ensure accuracy and consistency in the data analysis, an audit coder checked the researcher's application of the coding guide to approximately one-fourth of the data. When disagreements occurred in the coders' interpretations of the data, these differences were negotiated until agreement was achieved. Interrater reliability with the audit coder was $73 \%$. The interrater reliability coefficient was calculated by dividing the total number of agreements by the total number of decisions made. Ninety-six percent of the audit coder differences were based upon coding suggestions rather than disagreement to a 
particular code. An additional measure used to increase the trustworthiness of the findings was to make the written transcripts available to the participants so that they could verify the information obtained from interviews.

\section{Results and discussion}

Findings from this study provide insight into the processes that guide the design of interior textile products in a professional business setting. Additionally, findings revealed varied approaches among designers with respect to the processes employed to design interior textile products, suggesting that the process may be influenced by a company's or individual's differences, including one's commitment to a Design for the Environment (DfE) perspective.

\section{Design process for interior textile products}

Participants' narratives revealed that the design and development of interior textile products is delineated with respect to six main themes, or stages. These stages included resources and research, consumer need and trend identification, inspiration, creative exploration, product samples, and design completion. Designers' descriptions of and perspectives on the tasks, decisions, and concerns related to each stage of the design process are presented here. Similarities or differences in the accounts or perspectives of participants who employ a DfE orientation to textile design to other participants are noted when warranted.

\section{Resources and research}

The first theme identified through data analysis was resources and research, which established the foundation for initiating the design process. Collectively, participants expressed the importance of prior knowledge and experience and new information for informing decisions at all steps in the design process, thereby supporting Watkins' (1988) proposition that information creates a foundation for generating design solutions. For both conventional designers and DfE-oriented designers, this foundation included formal education and industry expertise. As demonstrated in the following quote, knowledge obtained through formal education was identified as having an important influence on design work:

There are a lot of foundational things that I learned as a design student with regard to things like color theory and things like that which obviously makes a difference in the quality of the product (Participant 1).

Explicit here is the notion that knowledge learned in school, has a direct impact on product quality. Likewise, industry experience was identified as an important to the design process as revealed in an explanation of fabric choice, "For different patterns you would use different fabric...different fabrics take dye differently...we kind of know all that stuff from doing it all these years" (Participant 9). This statement suggests that acquiring 'on-the job' experience or knowledge throughout one's career contributes to one's expertise when making decisions during the design process, such as selecting an appropriate fabric for pattern design and dye type. In addition to the foundation described above, DfE-oriented designers relied heavily on knowledge gained from research to inform later stages in the design process. Participants from medium sized 
DfE-oriented companies stated that in-house research and development departments or in-house environmental experts often serve as supportive sources of information for designers, whereas participants from small DfE-oriented companies indicated that they generally engaged in their own research to find more sustainable approaches to inform the design process. As the following quotes imply, there was general agreement among participants regarding the need to engage in research in order to obtain relevant environmental information and to make informed design decisions. When addressing the importance of research in prior design work, this DfE-oriented designer explicitly noted the need to obtain specific product and process information and knowledge prior to initiating projects:

I researched substrates [printing materials] that I wanted to use and researched [textile] printers who were sensitive to what I need and [were willing to] learn about sustainability and work with products they may have not worked with before (Participant 1).

This quote also implies the importance of partnering with textile printers (and other suppliers) who appreciate and understand the specific goals of a DfE project and are willing to obtain new knowledge in order to assist in achieving these goals. All five designers from DfE-oriented companies expressed the importance of being knowledgeable about advances in textiles as well as environmental standards and practices when making decisions about product materials. During another conversation on the subject of prior knowledge, one participant spoke specifically to the need to obtain information about sustainability and industry standards:

I do know a lot about standards, the Organic Trade Association [GOTS] has a set of standards and there are certain dyes to use...the way the plant is grown whether it is organic cotton or organic hemp... a list of things that you have to know (Participant 5).

Further, this statement demonstrates the need to possess knowledge beyond the realm of design, such as, how organic fibers are produced as well as industry standards related to DfE approaches to textile design. This information appeared to be particularly important to DfE-oriented designers who follow the Global Organic Trade Association's (GOTS) and other industry standards to make informed decisions relative to fabric selection and finishing processes.

\section{Consumer need and trend identification}

The second theme related to the design of interior textile products was the identification of consumers' needs and product trends. Interviews revealed that the act of choosing a design direction for a textile project required identification of a specific target market as well as understanding of consumer needs and knowledge of product trends. Although both conventional and DfE-oriented designers considered consumer needs, designer's narratives suggested that environmental considerations were central to consumer needs and market trends of DfE-oriented textile products. When describing the initiation of a project, one participant identified the role of textile designers as 'problem-solvers' for the target market: "We're kind of solution finders and each product should be answering a market question, or need or problem that's in the market" (Participant 12). Similarly, another participant stated that, "We assign different product end uses based on how we see the needs in the market...so we definitely look into the market and the needs and our 
weaknesses to assign what we launch or introduce" (Participant 5). Collectively, these statements convey the idea that textile design is driven by market needs or demands, rather than by a designer's personal sense of aesthetic quality or creativity, and that the product's end use will provide a solution to a consumer problem. Another strategy employed to develop direction for a project was to identify popular trends in areas other than textiles. For example, one company held an annual forecasting meeting at which the design team and other employees discussed trends in a predevelopment phase:

Everyone in the creative team, all the designers and marketing people discuss trends, social trends, technological trends, color trends, and materials (Participant 6).

The implication here is that all trends, even those outside of the interior textile industry, were appreciated as valuable for informing product development.

The narratives by DfE-oriented designers suggested that environmental consideration was important to their consumer needs and drove particular trends. For example, there was a perceived rise in consumer demand or need for DfE-oriented interior textile products even though the market for these products remains relatively small:

There's more organic cotton, more choices in construction of weaves, because customers are asking for it, even interior designers ask for it. I'm amazed that they say "I'm coming in because you're offering an eco fabric and I can't find it around here" (Participant 5).

This quote suggests that the trend toward DfE-oriented products is supported by the growing availability of DfE-oriented raw materials and fabric construction methods as well as by an increased awareness of DfE-oriented textile products among consumers. It also implies that the limited availability of such products creates a market opportunity for DfE-oriented companies. Although participants acknowledged an increase in the popularity of DfE-oriented products, one participant also spoke to inconsistencies in consumer demand for other DfE-oriented approaches, such as locally made products and hand stitched textiles:

We have customers that want a handmade product and that's part of the allure, but when they get it, if there's a slight imperfection because somebody has stitched or cut this by hand [they are disappointed]. People want to say they have a handmade product, but [they] want machine made consistency (Participant 10).

This quote addresses the challenge of meeting consumer demands or tastes for artisan textile products and simultaneously meeting consumer expectations for product quality that may be influenced by their experience with mass production methods or standards, such as with the noted example of regularity in stitching.

\section{Inspiration}

Participants explained that once the parameters of a project were set, inspiration was isolated as the starting point from which to engage in actual design work. All designers referenced the importance of inspiration in the design process and there was little difference among conventional and DfE-oriented designers with respect to their sources of inspiration. As evidenced by the following quote, participants referenced varied 
sources of inspiration including art, fashion, furniture, historic textiles, nature, and raw or intermediary materials:

Inspiration is where I start, and that comes from all different types of ideas whether historical as in archives, I do a lot of research from books, fashion is a big influence for me, when I travel, colors...the overall state of the world (Participant 4).

This statement presents inspiration as a reflection of the designer's interests and experience. In addition to tangible sources of inspiration, such as textile archives and color, inspiration also came from intangible sources such as global issues. Although participants frequently identified a broad range of inspiration sources, they also identified common inspiration sources. For example, three participants identified fashion (i.e., apparel) as a source of inspiration for their design choices. Another three participants referenced a specific artist or artistic style as a source of inspiration. Because the designers were often working within styles associated with the company's brand identity and existing collections, inspiration sometimes came from within the company's own collection of textile patterns: "We don't just design it as a pattern, we design it as a collection but the catch for me is that a product has to stand alone and speak on its own but work with existing ideas" (Participant 4). The challenge here is to create a cohesive collection, and at the same time design an individual product that exhibits unique characteristics. Two participants who employed a DfE-oriented approach to design stated that the act of being in nature and/or natural forms served as their primary source of inspiration: "I go on what I call 'trend hiking' because I really like to be out in nature so now I go out at least two times a week with my camera and look for inspiration" (Participant 3).

\section{Creative exploration}

After identifying the project direction and inspiration, designers engaged in creative exploration, supporting Margolin's (2007) claim that the work of designers is to partake in imaginative exploration that fosters solutions to present and future societal needs. For all participants, creative exploration involved putting design ideas to paper, either through hand drawing or a computer program, and then experimenting with design options. Considerations exhibited by DfE-oriented designers during the creative exploration stage were similar to those expressed by conventional designers', however, DfEoriented designers based many of their creative decisions upon the impact of materials and production methods on human health and the environment, which, in turn, defined their scope of exploration.

Creative exploration frequently involved experimenting with color, pattern, repeat, and fabric choice. As expressed by one designer, computer programs are often used to efficiently explore and experiment with different colors and repeats in order to create patterns: "I ultimately go to the computer, even if it's something that's hand done, and then manipulate it to put it into repeat and try different colors" (Participant 12). Participants also noted that the use of computer programs provided a more accurate representation (as compared to a hand drawing) of how the pattern would look when printed on fabric and allowed designers to easily view patterns in a variety of colorways prior to textile sample manufacturing. Almost all participants utilized technological tools and services during the 
design process, including the computer software Photoshop for pattern rending and Pantone, the color trend forecasting service for color selection.

The type of printing process utilized also, in part, influenced creative exploration with respect to the textile pattern. The following statements elucidate one designer's perspective on the distinction between the two printing processes, screen and digital printing:

With (rotary) screen printing you send the artwork to the mill, your finished repeated artwork, and they create a film from your artwork, so there's another layer that happens. It's someone else's hand that creates this film and then that's transferred to a screen that's stretched on a frame so the end product I happen to really, really love (Participant 5).

The interpretation here is that screen-printing results in a more individualized product, thus evoking a more traditional or simple approach to craftsmanship, whereas digital printing may be more demanding on the designer because it reflects the ideal associated with modern technology, or the belief that the artwork has to be exact, as illustrated in the following quote:

The digital world is a whole different animal because the artwork has to be really perfect because that digital file is what's going to happen on the fabric and if it's not drawn properly and the repeat's off that's what you're going to have on your fabric, it goes right from your file on the computer to the cloth, so I really spend more time on the artwork for the digital printing (Participant 5).

Although creating the artwork for digital printing may be more demanding-requiring more time and precision - than for screen-printing, the advantages are flexibility in fabric color and yardage minimums. For these reasons, two designers expressed the opinion that digital printing was at the forefront of positive DfE technological advances in the industry. However, owing to the demanding nature of the digital printing process, three participants expressed the belief that the quality of digital prints was inferior to what could be achieved with woven or screen-printed textiles.

Another aspect of creative exploration for multiple participants was the examination and selection of fabrics. Designers explained how fabric constructions (e.g., weave structures) were chosen based upon the type of pattern, printing process, color, price, and the intended end use of the finished product. Further, content analysis of interview data revealed that designers' considerations relative to fabric construction also were influenced by aesthetic qualities, including understanding of the relationship between fabric selection and the printing process:

You have to know that every pattern is not going to translate to every base cloth. You're going to get a very different look printing on a jersey as you would on a linen and you have to be aware of that and you have to know the printing process and if what you're imagining is even going to translate (Participant 10).

The ability to visualize how a pattern may render on different types of fabric will influence fabric selection, which will impact the appearance and quality of the design in its finished form. 
As previously stated, DfE-oriented designers based their decisions upon the impact of materials and production methods on human health and the environment. For example, one designer only sourced organic Belgian linen that could be air freighted to avoid the potential formaldehyde contamination in shipping containers. Another DfE-oriented company was GOTS (Global Organic Textile Standard) certified, which limited both the fabric and manufacturing options for the designer. DfE-oriented designers also noted that environmental impact was of primary importance in fabric selection:

I found a completely recycled fabric...50\% organic cotton, $30 \%$ organic hemp and some recycled polyester. There are a lot of folks who feel differently about polyester... but I knew having some polyester in the fabric was going to help as far as draping...So I folded it and tested it and looked at how it would drape (Participant 1).

This quote demonstrates the value of recycled fabrics with respect to meeting environmental criteria and conveys the importance of aesthetic qualities when choosing fabrics. Implicit here is that fabric selection may involve some compromise; for this designer, recycled polyester was an acceptable choice for what constitutes an environmentally sustainable material.

\section{Product samples}

The fifth theme identified relates to the acquisition or manufacturing of textile product samples. Upon approval of the design, more than half the participants reported that they engage in the production of textile product samples and that they relied on experts at the textile mills to provide assistance in the product sampling process including, but not limited to, fiber sourcing, fabric weaving, and textile printing. Prior to product manufacturing, textile product samples are inspected for appearance, tested for performance and quality (e.g., abrasion resistance, washability, shrinkage), and sometimes revised to modify visual elements such as color and/or pattern. Although the development of product samples was common among both conventional and DfE-oriented designers, for the DfE-oriented designers from small companies, the development of samples was directly related to their prevailing choice to use natural fibers, which are less consistent in hand and color quality. The value of a product sample for assessing the aesthetic quality of a finished product relative to desired outcomes is expressed in the following quote:

We see a sample...or a strike off of our design and there's tweaks that go on...we may loop back and reconstruct a bit or adjust the design once we see it in a big piece or try it in a few colorways to make sure it colors in a way we are looking [for] (Participant 4).

Similarly, participants noted that product samples are valuable for assessing performance quality (i.e., for material testing purposes). Designers from the four companies that sell contract textiles explained that comprehensive material testing was necessary to meet the established regulations for commercial textiles, and that testing was conducted by both internal units and external organizations to ensure that the products meet standards for performance and safety: 
We have trials and we have to test yardage...we analyze for different quality, go through a battery of tests because it's a commercial end use we have to meet tons of requirement and standards, flame redundancy and abrasion, performance (Participant 6).

Explicit in this quote is the importance of quality assurance and assessment in the development of commercial textiles, including the need to meet industry established standards of quality, performance, and safety for fabrics, based upon product end use. Also implied here is the need on the part of the designers to be knowledgeable about industry standards as well as the specific types of testing methods used to assess quality, performance, and safety.

As previously stated, designers from smaller DfE-oriented companies expressed the need for color and print sampling owing to inconsistencies with DfE fabric choices and printing processes. For example, a DfE-oriented designer, who uses hemp fabrics only, noted a potential for color inconsistencies when using natural fibers: "Color specifically is the biggest issue...since this is all natural fibers, any number of things can happen, it can come back from the mill sometimes a different color because it's hemp" (Participant 5). Similarly, another designer stressed the importance of testing prints every time fabric is sourced owing to the potential for color variation in DfE fabrics:

Because of the recycled content in combination of the natural content you get a lot of variation in the color of the fibers, and you also get a lot of little slugs in the fibers and because it's only surface printing, if there is a little slug that's raised, there's no printing there...so I order a minimum that my printer needs and do some testing (Participant 1 ).

As such, for DfE designers choosing to work with natural fibers, inconsistencies in the fabric surface resulted in the need for additional sampling and quality control.

\section{Design completion}

The final theme related to the design of interior textile products is the completion of the process culminating in the initiation of product marketing. All Participants viewed the design process as finished when products were introduced into the marketplace or delivered to a client. Although all designers referenced their contribution to marketing and selling products, one distinction among conventional and DfE-oriented designers at this stage of the process was in reference to the type of information provided in marketing materials. DfE-oriented designers specifically spoke to consumer demand for information about the finished product, specifically in regard to the potential human health and environmental impacts of the textile manufacturing processes:

The textile supply chain is a fairly deep and long one and accessing data from far upstream has become more important to our end customers, there's a lot of demand for transparency whether that be around issues of...how employees are treated... chemical inputs and their potential health hazards (Participant 11).

Thus, DfE-oriented designers must possess holistic understanding and knowledge of the textile supply chain, especially in regard to socially responsible and sustainable practices, in order to provide customers with complete confidence in their purchase decisions. 
DfE-oriented designers also expressed a lack of consumer knowledge in regard to human health and environmental impact of the textile industry, and the need to educate consumers:

You have to create a product people want regardless of the sustainability profile... then you have the whole process of educating people about...bringing materials into [their] home that may be off-gassing and how much time they spend inside around these materials (Participant 1).

Explicit here is the need to educate consumers about the issue of off-gassing and poor indoor air quality, which can occur in the home environment through the use of glues and stain resistant finishes on carpeting, upholstered furniture, and other textile products. The challenge is how to educate consumers so that they may make fully informed choices relative to the selection of environmentally friendly or sustainable interior textile products.

\section{Conclusion}

The present work contributes to our understanding of the processes that inform the design of interior textile products and highlights the similarity and differences between conventional and Design for the Environment (DfE) practices. One key distinction from earlier examinations of design processes related to textiles and apparel is that the present study examined the perspectives of professionals working in the industry, rather than the perspectives of educators or design students (Gam et al., 2009; LaBat and Sokolowski, 1999; Parsons and Campbell, 2004; Lamb and Kallal, 1992, Watkins, 1988). Differences in research participants and product focus (textiles vs. apparel) aside, however, accounts of the design process as provided by both conventional and DfEoriented professional designers of interior textiles were, to some degree, consistent with accounts reported in prior research. The present study revealed six themes or distinct stages in the process undertaken to design interior textile products, four of which (i.e., consumer need and trend identification, creative exploration, product samples, and design completion) are consistent with findings from previous research. Differences from prior research were revealed with respect to the depth and specificity of considerations noted by participants when addressing individual themes or stages. For example, although prior research on the design process as it relates to textiles and apparel generally includes a stage related to material exploration (Gam et al., 2009; Labat and Sokolowski, 1999; Lamb and Kallal, 1992; Parsons and Campbell, 2004), discussion of the specific activities and decision-making at this stage is somewhat limited. In this study, when participants addressed creative exploration, they frequently spoke to the importance of multiple product qualities (e.g., aesthetics, performance, environmental impact) that guide material selection and how these qualities impact final design decisions. Also, participants frequently noted the relationship between the designer and the textile mill as a significant factor in design decisions. This may be, in part, be related to the nature of interior textile products. Interior textile products are designed to embody both aesthetic and performance qualities, thereby creating the need for designers to focus heavily upon material sourcing during the creative exploration stage of the process. 
Findings revealed DfE-oriented designers and conventional designers did not differ in their design process however, the focus and scope of decision-making within each stage of the design process allowed for an additional component for DfE-oriented designers, thus providing some understanding of how commitment to a DfE orientation may influence the design of interior textile products. For example, when addressing the resources and research stage of the design process, DfE-oriented designers in this study gave considerably more importance to being knowledgeable about the latest advances in textiles as well as environmental standards and practices than did the other designers, making specific references to the selection of raw material based on environmental criteria employed by organizations, such as GOTS. When speaking to consumer needs and product trends, all participants acknowledged that understanding consumer needs for aesthetics and performance was central to the design process; however, only DfEoriented designers explicitly addressed consumers' growing need for sustainable textiles. Also, unlike conventional designers who may explore and/or select materials and production methods based solely upon aesthetics or performance considerations, DfE-oriented designers also considered the potential impacts of materials and production methods on human health and the environment during the creative exploration stage. Participants' narratives on design completion revealed that designers play an integral role in product marketing, however, DfE-oriented designers need to possess comprehensive knowledge of socially responsible and sustainable practices employed throughout the textile supply chain to provide consumers with confidence in their decision-making.

Lastly, findings provide some support for the application of Handfield et al.'s (2001) environmental product design and development model to the experience of DfEoriented designers of interior textile products. Most notably, the creative exploration theme identified in the present study is similar to the product design stage in the Handfield et al. (2001) model; the stage during which decisions related to product specifications, including raw material selection are made. Prominent differences between these conceptualizations of the design process include the emphasis that designers in this study placed upon research and resources as well as consumer need and trend identification, which clearly delineated these as unique phases in the design of interior textile products. This difference may, in part be explained by the 'fashion' aspect of interior textile products. This may also explain the difference in the product launch stage which is somewhat similar to the conclusion of the design process as described by the designers in this study; however, the focus among interior textile designers was market acceptance rather than assessment of the environmental impacts of the products; any reference to interior textile product evaluation at this stage of the process was in the form of consumer feedback/satisfaction.

\section{Implications}

Findings from this study provide both practical and theoretical implications regarding the processes undertaken to design interior textile products. One implication is that interior textile design, especially for DfE-oriented designers, involves a holistic approach to the design and development of products, with special emphasis on foundational knowledge, inspiration, and product trends. Further, this research suggests that the interior textile design process is heavily informed by expectations or standards for inhome product performance, which directly impacts the focus of the design process or 
work. This difference in product type and performance expectations may, in part, explain distinctions between design processes employed for apparel and interior textiles, specifically in regard to how information pertaining to consumer needs, raw materials, and industry performance standards are used to inform the processes.

The broad implication related to DfE is that the design process continues to evolve through the implementation of new technologies (both product and process related) and new ways of seeing, specifically the belief that designers can act as instruments of social change by embracing a DfE orientation and thereby reducing the negative impacts that interior textile products have on human health and the environment. The implication is that the processes undertaken by DfE designers do not necessarily differ from conventional approaches to interior textile product design, but rather that these processes are expanded to include consideration of multiple human health and environmental factors or impacts. Variations in design processes owing to the influence of business practices rather than human health and environmental impacts, and thus not reflective of ideal DfE practices, were noted, however. Designers observed that DfEoriented approaches to design were sometimes hindered as industry, consumer, and technological limitations created hurdles for designers attempting to reduce the potentially negative impact of their work on human health and the environment. Such observations suggest that design processes cannot be separated from the conditions and conventions of the industries in which the actual product design and development take place. These observations also suggest that as technology advances there will be a need for more research to explore the future progression of DfE in the interior textile product industry as well as in other industry settings.

\section{Limitations and future research}

One limitation of this work was the relatively small number of textile designers who participated in the study. The size and diversity of the sample may have been limited by the fact that industry professionals may be less likely than individuals from other populations to participate in academic research owing to time constraints and a lack of willingness to share company information. Although the number of participants was deemed satisfactory owing to the niche sector of the interior textile industry that was investigated and data saturation, a larger sample may have provided additional insights into interior textile product design processes. A second possible limitation relates to the method employed to collect data for this study. Specifically, the use of telephone, rather than face-to-face, interviews may have impacted the rapport established between the interviewer and the participants, which may have influenced the nature of the participants' responses.

Findings provide a basis for future examinations of DfE-oriented approaches to interior textile product design, particularly among designers who are employed in professional settings (rather than classroom settings). In the future, researchers might conduct analyses of the individual themes or stages identified in this study to provide greater understanding of the details and complexities involved in the design and development of interior textile products in professional business settings. Researchers also might investigate the methods that designers employ to measure environmental efforts and outcomes during each stage of the design process and explore how these efforts and outcomes have informed current design philosophies and practices. 
Competing interests

The authors declare that they have no competing interests.

\section{Authors' contributions}

SC developed the literature review and theoretical framework, conducted the telephone interviews, and drafted the manuscript. KHH guided the development of the research questions, theoretical framework, and reporting of the results. All authors read and approved the final manuscript.

Received: 5 November 2014 Accepted: 21 April 2015

Published online: 25 May 2015

\section{References}

Bye, E. (2010). A direction for clothing and textile design research. Clothing and Textiles Research Journal, 28(3), 205-217.

Clark, H. (2008). SLOW+ FASHION_an oxymoron-or a promise for the future...? Fashion Theory: The Journal of Dress Body \& Culture, 12(4), 427-446.

Fuad-Luke, A. (2009). Design activism: beautiful strangeness for a sustainable world. London: Earthscan.

Gagnon, B, Leduc, R, \& Savard, L. (2012). From a conventional to a sustainable engineering design process: different shades of sustainability. Journal of Engineering Design, 23(1), 49-74.

Gam, HJ, Cao, H, Farr, C, \& Heine, L. (2009). C2CDA: a sustainable apparel design and production model. International Journal of Clothing Science and Technology, 21(4), 166-179.

Gam, HJ, Cao, H, Bennett, J, Helmkamo, C, \& Farr, C. (2011). Application of design for disassembly in men's jacket: a study on sustainable apparel design. International Journal of Clothing Science and Technology, 23(2), 83-94.

Glaser, BG, \& Strauss, AL. (1967). The discovery of grounded theory: strategies for qualitative research. Chicago: Aldie.

Glesne, C. (2011). Becoming qualitative researchers: an introduction (4th ed.). Boston: Pearson.

Guetzkow, H. (1950). Unitizing and categorizing problems in coding qualitative data. Journal of Clinical Psychology, 6(10), 47-58.

Handfield, RB, Melnyk, SA, Calantone, RJ, \& Curkovic, S. (2001). Integrating environmental concern into the design process: the gap between theory and practice. IEEE Transactions on Engineering Management, 48(2), 189-208.

Kim, B. (2010). Green design: studies about fashion handbag. In 2010 IEEE 11th International Conference on Computer-Aided Industrial Design \& Conceptual Design (CAIDCD) (2nd ed., pp. 815-819). Retrieved from http://ieeexplore.ieee.org/xpl/ articleDetails.jsp?arnumber $=5681896$.

Laamanen, T-K, \& Seitamaa-Hakkarainen, P. (2008). Sources of inspiration and mental image in textile design process. Art, Design \& Communication in Higher Education, 7(2), 105-119.

LaBat, KL, \& Sokolowski, SL. (1999). A three stage design process applied to an industry-university textile product design project. Clothing and Textile Research Journal, 17(1), 11-20.

Lamb, JM, \& Kallal, MJ. (1992). A conceptual framework for apparel design. Clothing and Textiles Research Journal, 10(2), 42-47.

Lawson, B. (1997). How designers think: The design process demystified (3rd ed.). Oxford: Architectural Press.

Mace, MA. (1997). Toward an understanding of creativity through a qualitative appraisal of contemporary art making. Creativity Research Journal, 10(2-3), 265-278.

Margolin, V. (2007). Design, the future and the human spirit. Design Issues, 23(3), 4-15.

May-Plumlee, T, \& Little, TJ. (2006). Proactive product development integrating consumer requirements. International Journal of Clothing Science and Technology, 18(1), 53-66.

McDonough, W, \& Braungart, M. (2002). Cradle to cradle: remaking the way we make things. New York: North Point.

Parsons, JL, \& Campbell, JR. (2004). Digital apparel design process: placing a new technology into a framework for the creative design process. Clothing and Textiles, 22(1/2), 88-98.

Ramani, K, Ramanujan, D, Bernstein, WZ, Zhao, F, Sutherland, J, Handwerker, C, Choi, J-K, Kim, H, \& Thurston, D. (2010). Integrated sustainable life cycle design: a review. Journal of Mechanical Design, 132(9), 1-15.

Shank, GD. (2002). Qualitative research: a personal skills approach. Upper Saddle River, NJ: Merrill Prentice Hall.

Stegall, N. (2006). Designing for sustainability: a philosophy for ecologically intentional design. Design Issues, 22(2), 56-63.

Strauss, A, \& Corbin, J. (1998). Basics of qualitative research (2nd ed.). Thousand Oaks, CA: Sage Publications.

Studd, R. (2002). The textile design process. The Design Journal, 5(1), 35-49.

Watkins, SM. (1988). Clothing: the portable environment (2nd ed.). Ames, IA: lowa State University Press.

Yang, Q, Yu, S, \& Sekhari, A. (2011). A modular eco-design method for life cycle engineering based on redesign risk control. International Journal of Advanced Manufacturing Technology, 56(9), 1215-1233.

\section{Submit your manuscript to a SpringerOpen ${ }^{\circ}$ journal and benefit from:}

- Convenient online submission

- Rigorous peer review

- Immediate publication on acceptance

- Open access: articles freely available online

- High visibility within the field

- Retaining the copyright to your article

Submit your next manuscript at $\gg$ springeropen.com 